\title{
EFFECT OF TEMPERATURE ON HEAT TRANSFER COEFFICIENT OF TITANIUM DIOXIDE IN ETHYLENE GLYCOL-BASED NANOFLUID
}

\author{
K. Abdul Hamid ${ }^{1}$, W.H. Azmi ${ }^{1 *}$, Rizalman Mamat ${ }^{1}$, N.A. Usri ${ }^{1}$ and G. Najafi ${ }^{2}$ \\ ${ }^{1}$ Faculty of Mechanical Engineering, Universiti Malaysia Pahang, \\ 26600 Pekan, Pahang, Malaysia \\ *Email: wanazmi2010@gmail.com \\ Phone: +6094246338; Fax: +6094242202 \\ ${ }^{2}$ Biosystems Engineering Department, Tarbiat Modares University, \\ P.O. Box 14115-111, Tehran 14114, Iran
}

\begin{abstract}
Nanofluid as a coolant has potential for use in the heat transfer field because of its augmentation in thermal properties that offers advantages in heat transfer. Research on various working temperatures is still ongoing in the nanofluid field. This study focused on the effect of temperature on heat transfer behavior using titanium dioxide or $\mathrm{TiO}_{2}$ nanofluid as the working fluid in forced convection. The heat transfer coefficient was determined for flow in a circular tube under constant heat flux boundary conditions. The experiment was conducted with a Reynolds number less than 25000 with concentrations of $\mathrm{TiO}_{2}$ nanofluid at $0.5 \%, 1.0 \%$ and $1.5 \%$. At $30^{\circ} \mathrm{C}$, the maximum enhancement of $9.72 \%$ for $1.5 \%$ volume concentration was observed. Enhancements of $22.75 \%$ and $28.92 \%$ were found at $50^{\circ} \mathrm{C}$ and $70^{\circ} \mathrm{C}$, respectively under similar nanofluid concentrations. The nanofluid performance was significantly influenced by working temperature. The heat transfer enhancement of $\mathrm{TiO}_{2}$ nanofluid was considerably improved at higher working temperature and high concentration because of the improvement of thermal properties.
\end{abstract}

Keywords: heat transfer coefficient; nanofluid; titanium dioxide; ethylene glycol

\section{INTRODUCTION}

Nanofluid, which is found as solid-liquid mixture in metallic or nonmetallic nanoparticle suspension, can be categorized as a new class of fluid that has important effects on thermal properties. It therefore has potential for use in cooling systems to improve the heat transfer ability [1-4]. Such ability in terms of improving the thermal transport of nanofluids is a major reason for the spread of research on nanofluid heat transfer. Nanofluid study began with Choi [5], who examined thermal conductivity enhancement of fluid with nanoparticles. Later, Eastman et al. [6] focused on the thermal conductivity of nanofluids. Many researchers have conducted studies on the thermal properties of nanofluids such as thermal conductivity and rheological behavior that affect their performance $[4,7,8]$. According to a review study by Ravisankar and Chand [9] and Azmi et al. [3], the study of nanofluid properties is important as they contribute significantly to heat transfer performance. Said et al. [10] conducted a study on the thermo-physical properties of $\mathrm{Al}_{2} \mathrm{O}_{3}$ in EG/water mixture (by mass) nanofluids. They showed that thermal conductivity linearly increased with concentration of nanofluid. Sundar et al. [11] used a mixture of ethylene glycol and water with $\mathrm{Fe}_{3} \mathrm{O}_{4}$ 
nanoparticles and found that the thermal conductivity of nanofluids increased as the concentration and temperature of the nanofluids increased. Additionally, a study by Javadi et al. [12] found that the types of nanoparticles used also contributed to the thermal conductivity enhancement whereby $\mathrm{Al}_{2} \mathrm{O}_{3}$ and $\mathrm{TiO}_{2}$ were found to have higher enhancement than $\mathrm{SiO}_{2}$. Also, thermal conductivity was affected by particle size and the stability of the nanofluid [13-16].

A study on forced convection using $\mathrm{Al}_{2} \mathrm{O}_{3}$ nanofluid for laminar flow in a plain tube by Sharma and Syam Sundar [17] found that the twisted tape inserts contributed to the enhancement of the heat transfer of the applied nanofluid in the system. Hojjat et al. [18] conducted a study on forced convection heat transfer of non-Newtonian nanofluids in a circular tube with constant wall temperature under turbulent flow using nanoparticles of $\gamma-\mathrm{Al}_{2} \mathrm{O}_{3}, \mathrm{TiO}_{2}$ and $\mathrm{CuO}$. The results of his experiment showed that the heat transfer enhancement of the nanofluids was higher than that of the base fluid and increased with increases in nanofluid concentration. The increases in effective thermal conductivity contributed greatly to the forced convection heat transfer. Ding et al. [19] examined nanofluid forced convection heat transfer using aqueous and ethylene glycolbased $\mathrm{TiO}_{2}$ nanofluid and found that the nanofluid exhibited a higher effective thermal conductivity. The interesting finding was that the heat transfer coefficient enhancement for the aqueous-based $\mathrm{TiO}_{2}$ nanofluids showed much greater enhancement than the thermal conduction enhancement. However, for ethylene glycol-based $\mathrm{TiO}_{2}$ nanofluid deterioration occurred because of the effect of particle migration on the thermal boundary layer thickness. Azmi et al. [20] placed an insert in a tube section for forced convection withReynolds numbers from 8000 to 30000 at an average temperature of $30{ }^{\circ} \mathrm{C}$ and found that $\mathrm{TiO}_{2}$ water-based nanofluid shows enhancement of up to $23.2 \%$ at a concentration of $1.0 \%$. Duangthongsuk and Wongwises [21] conducted an experimental study on $\mathrm{TiO}_{2}$ water-based nanofluid in a heat exchanger. The effect of the nanofluid temperature was clearly affected at higher Reynolds numbers where the heat transfer coefficient was higher at lower nanofluid temperatures. This was because the decrease in nanofluid temperature contributed to an increase in the heat transfer rate, and resulted in an increase in the heat transfer coefficient. However, the study was only performed for one concentration, $0.2 \%$. Thus, the effect of other parameters such as variation in nanofluid concentration is unknown.

The effect of working temperature for the same types of nanofluid in forced convection is still little known. Furthermore, previous literature does not clearly state at which temperature the experiments were conducted and room temperature $\left(27^{\circ} \mathrm{C}\right)$ is therefore assumed. Therefore, the temperatures selected in the present study were $30^{\circ} \mathrm{C}$, $50^{\circ} \mathrm{C}$ and $70^{\circ} \mathrm{C}$ to provide better observation on the heat transfer performance of the nanofluid and how the nanofluid concentration affected the heat transfer.

\section{METHODS AND MATERIALS}

\section{Preparation of Nanofluid}

The type of nanoparticle used in this study was $\mathrm{TiO}_{2}$, which was supplied by US Research Nanomaterials, Inc. in water dispersion with weight concentration of $25 \mathrm{wt} \%$. The average size of $\mathrm{TiO}_{2}$ nanoparticles was $50 \mathrm{~nm}$. The base fluid used was a mixture of distilled water and ethylene glycol in a volume ratio of 60:40. The distilled water was prepared in the laboratory with a distiller. Ethylene glycol AR grade was procured from QRec Asia with purity of $99.5 \%$. The $\mathrm{TiO}_{2}$ nanofluid was then prepared by converting it 
from weight concentration to volume concentration using Eq. (1) and diluting it to a new concentration using Eq. (2). $\mathrm{TiO}_{2}$ nanofluid was prepared at volume concentrations of $0.5 \%, 1.0 \%$ and $1.5 \%$. The nanofluid samples were then immersed in an ultrasonic bath for two hours to ensure their stability for a longer time.

$$
\begin{array}{r}
\phi=\frac{\omega \rho_{b f}}{\frac{\omega}{100} \rho_{b f}+\rho_{p}\left(1-\frac{\omega}{100}\right)} \\
\Delta V=\left(V_{2}-V_{1}\right)=V_{1}\left(\frac{\phi_{1}}{\phi_{2}}-1\right)
\end{array}
$$

where $\phi$ is volume concentration in $\% ; \omega$ is weight concentration in $\% ; \rho_{b f}$ is density of base fluid in $\mathrm{kg} / \mathrm{m}^{3} ; \rho_{p}$ is density of nanoparticles in $\mathrm{kg} / \mathrm{m}^{3} ; \Delta V$ is additional volume in $\mathrm{mL} ; V_{1}$ is initial volume in $\mathrm{mL} ; V_{2}$ is final volume in $\mathrm{mL} ; \phi_{1}$ is initial volume concentration in $\%$ and $\phi_{2}$ is final volume concentration in $\%$.

\section{Thermo-Physical Properties}

The measurement of thermal conductivity and viscosity for each concentration of $\mathrm{TiO}_{2}$ nanofluid was conducted using a KD2 Pro Thermal Properties Analyzer and Brookfield LVDV-III Ultra Rheometer. The solid-liquid mixture relation given by Eqs. (3) and (4) gave the density and specific heat of the nanofluid.

$$
\begin{aligned}
\rho_{n f} & =\varphi \rho_{p}+(1-\varphi) \rho_{b f} \\
C_{n f} & =\frac{(1-\varphi)(\rho C)_{b f}+\varphi(\rho C)_{p}}{(1-\varphi) \rho_{b f}+\varphi \rho_{p}}
\end{aligned}
$$

where $\rho_{n f}$ is the density of nanofluid in $\mathrm{kg} / \mathrm{m}^{3} ; \varphi=\phi / 100$ is the volume fraction; $C_{n f}$ is the specific heat of nanofluid in $\mathrm{J} / \mathrm{kg} . \mathrm{K} ; C_{b f}$ is the specific heat of base fluid in $\mathrm{J} / \mathrm{kg} . \mathrm{K} ; C_{p}$ is the specific heat of nanoparticles in $\mathrm{J} / \mathrm{kg} . \mathrm{K}$.

The thermo-physical properties for the water/ethylene glycol mixture and $\mathrm{TiO}_{2}$ nanofluid at different concentrations are shown in Table 1 for temperatures of 30, 50 and $70{ }^{\circ} \mathrm{C}$, respectively.

\section{Forced Convection Apparatus}

The forced convection experimental apparatus consisted of a test section, flow meter, pump, collecting tank, chiller and data logger as shown in Figure 1. The horizontal tube in the test section was a copper tube with inner and outer diameter of $16 \mathrm{~mm}$ and 19 $\mathrm{mm}$, respectively. Two nichrome heaters with a rating of $1.5 \mathrm{~kW}$ were installed in the test section. The whole test section was $1.5 \mathrm{~m}$ long and was insulated with ceramic fiber. Seven K-Type thermocouples were installed in the test section at the inlet, outlet and between the inlet and outlet. 
Table 1. Thermo-physical properties of $\mathrm{TiO}_{2}$ nanofluid.

\begin{tabular}{|c|c|c|c|c|}
\hline \multicolumn{5}{|c|}{ Temperature: $30^{\circ} \mathrm{C}$} \\
\hline $\begin{array}{c}\text { Volume } \\
\text { Concentration, } \phi \\
(\%)\end{array}$ & $\begin{array}{l}\text { Density, } \rho \\
\left(\mathrm{kg} / \mathrm{m}^{3}\right)\end{array}$ & $\begin{array}{l}\text { Specific } \\
\text { Heat, } C \\
(\mathrm{~J} / \mathrm{kg} . \mathrm{K})\end{array}$ & $\begin{array}{c}\text { Thermal } \\
\text { Conductivity, } k \\
(\mathrm{~W} / \mathrm{m} . \mathrm{K})\end{array}$ & $\begin{array}{l}\text { Viscosity, } \mu \\
(\mathrm{kg} / \mathrm{m} . \mathrm{s})\end{array}$ \\
\hline 0.0 & 1055.39 & 3502.0 & 0.413 & 0.00240 \\
\hline 0.5 & 1071.26 & 3446.5 & 0.418 & 0.00251 \\
\hline 1.0 & 1087.14 & 3392.7 & 0.433 & 0.00265 \\
\hline 1.5 & 1103.01 & 3340.4 & 0.441 & 0.00279 \\
\hline \multicolumn{5}{|c|}{ Temperature: $50^{\circ} \mathrm{C}$} \\
\hline 0.0 & 1045.35 & 3569.0 & 0.428 & 0.00157 \\
\hline 0.5 & 1061.27 & 3511.7 & 0.432 & 0.00164 \\
\hline 1.0 & 1077.20 & 3456.0 & 0.448 & 0.00177 \\
\hline 1.5 & 1093.12 & 3402.0 & 0.488 & 0.00182 \\
\hline \multicolumn{5}{|c|}{ Temperature: $70^{\circ} \mathrm{C}$} \\
\hline 0.0 & 1033.37 & 3636.0 & 0.438 & 0.00111 \\
\hline 0.5 & 1049.35 & 3576.7 & 0.443 & 0.00125 \\
\hline 1.0 & 1065.34 & 3519.1 & 0.462 & 0.00143 \\
\hline 1.5 & 1081.32 & 3463.3 & 0.501 & 0.00148 \\
\hline
\end{tabular}

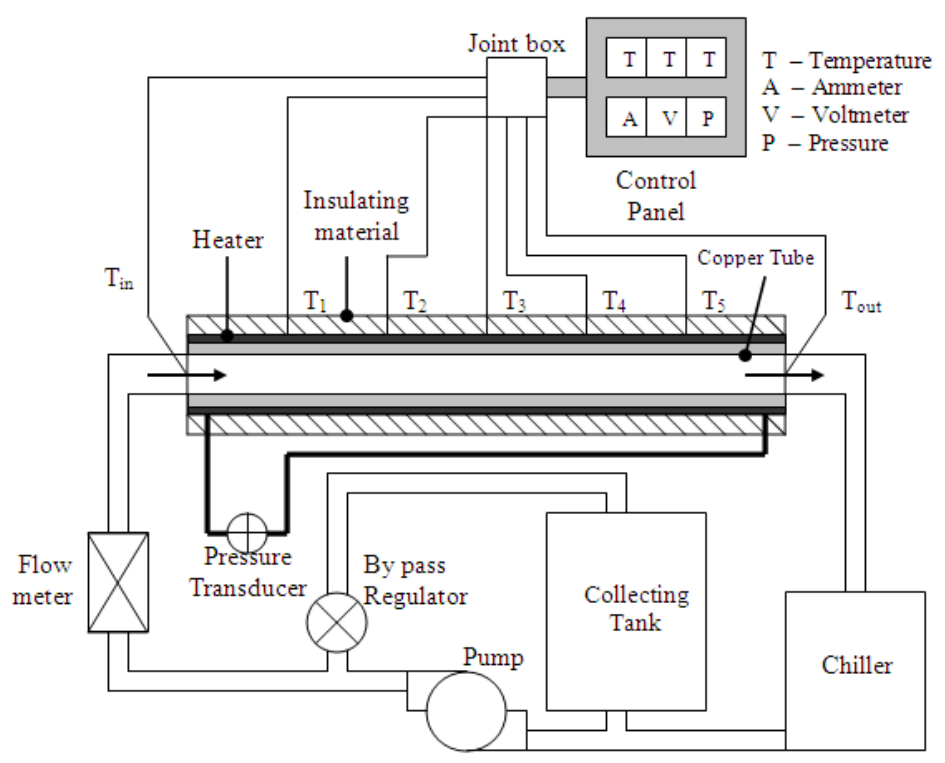

Figure 1. Schematic diagram of the forced convection apparatus.

The thermocouples were connected to the data logger to record the temperatures at the specific locations. A constant input power to the test section was maintained at $600 \mathrm{~W}$, controlled by the voltage regulator. The chiller provided constant inlet temperature of 30,50 and $70^{\circ} \mathrm{C}$. The flow meter measured the flow rate of the circulating fluid in a range of 0 to 30 LPM. A differential pressure transducer was mounted at the inlet and outlet of the test section to measure the pressure drop and then recorded it through the data logger. Experimental testing of the nanofluid for convective heat transfer followed the procedure used by Azmi et al. [20, 22]. An experimental study on the working temperature effect of $\mathrm{TiO}_{2}$ nanofluid was undertaken for bulk 
temperatures of 30,50 and $70^{\circ} \mathrm{C}$, at volume concentrations of $0.5 \%, 1.0 \%$ and $1.5 \%$ for Reynolds numbers less than 25000 .

\section{RESULTS AND DISCUSSION}

\section{Thermal Conductivity and Viscosity Measurement}

The measured values of thermal conductivity and viscosity were compared with those in the ASHRAE Handbook [23] for a mixture of water and ethylene glycol. As shown in Figure 2, the data for the base fluid compared with ASHRAE data were in good agreement. Figure 2(a) shows that the thermal conductivity of nanofluid increased with volume concentration and temperature. The movement of particles through Brownian motion contributed to the improvement of thermal conductivity with temperature. A similar trend was found by Sundar et al. [11] and Abdul Hamid et al. [24]. Figure 2(b) presents the variation of temperature with nanofluid viscosity. As temperature increases, the nanofluid viscosity decreases exponentially, following the base fluid trend and in agreement with the data given by Anoop et al. [25] and Usri et al. [26].

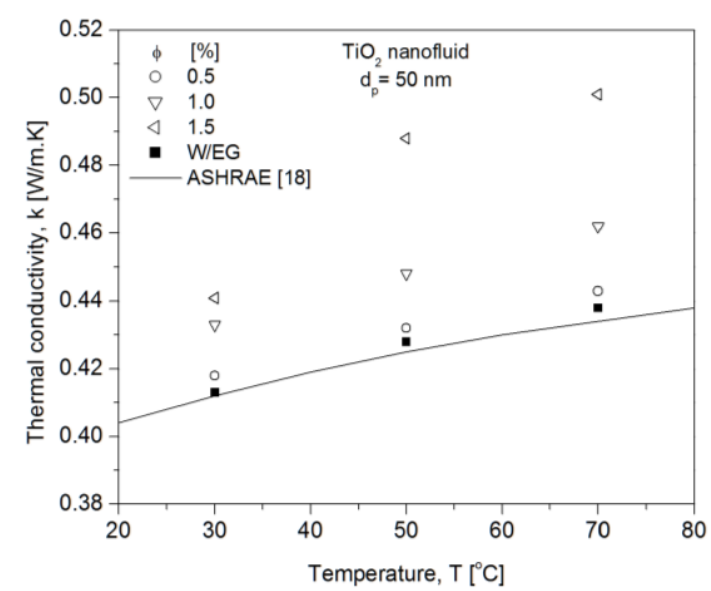

(a) Thermal conductivity

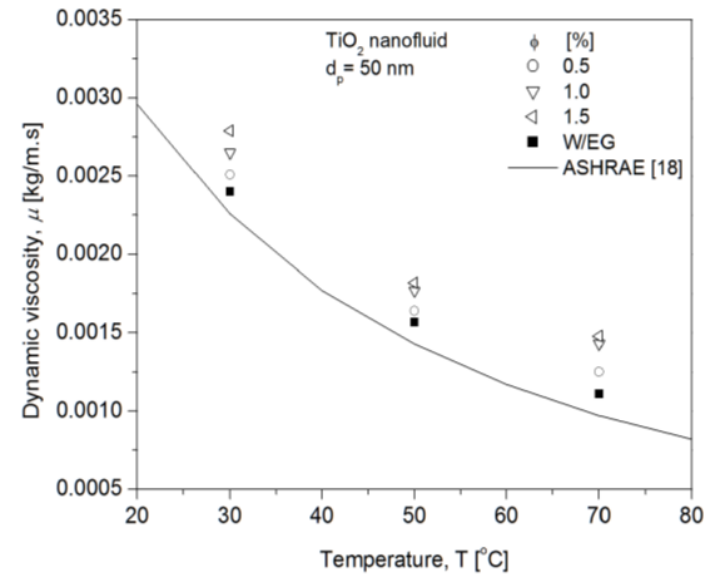

(b) Viscosity

Figure 2. Variation of thermal conductivity and viscosity of $\mathrm{TiO}_{2}$ nanofluid with temperature.

\section{Forced Convection Heat Transfer}

In Figure 3(a) [27], the heat transfer coefficient at working temperature of $30{ }^{\circ} \mathrm{C}$ and volume concentration of less than $1.5 \%$ is distributed in a lower region of the base fluid. It shows that $\mathrm{TiO}_{2}$ nanofluid at lower concentration is not able to enhance heat transfer for a working temperature of $30^{\circ} \mathrm{C}$. The decrease in heat transfer coefficient is likely owed to the particle migration mechanism whereby the particles tend to concentrate in the pipe center, resulting in a decrease in the boundary layer thickness [28].The high temperature $50^{\circ} \mathrm{C}$ and $70^{\circ} \mathrm{C}$ represent good correspondence value of heat transfer coefficient as shown by Figures 3(b) and 3(c). The data for higher volume concentration appear to show a high value of heat transfer coefficient with respect to Reynolds number and temperature. The remarkable increase in the thermal conductivity of the nanofluid over its base fluid (W/EG) acts as an advantageous factor, leading to a further 
enhancement in the average heat transfer coefficient. Elevating the operating temperature of the nanofluid can significantly improve enhancement of the average heat transfer coefficient [29]. The average enhancement of heat transfer coefficient in all data from Figures 3 (a)-(c) is presented in Table 2.

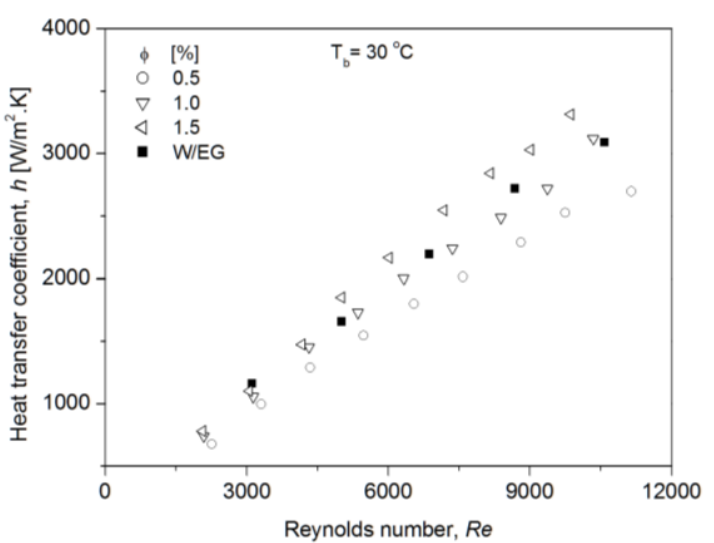

(a) $30^{\circ} \mathrm{C}$

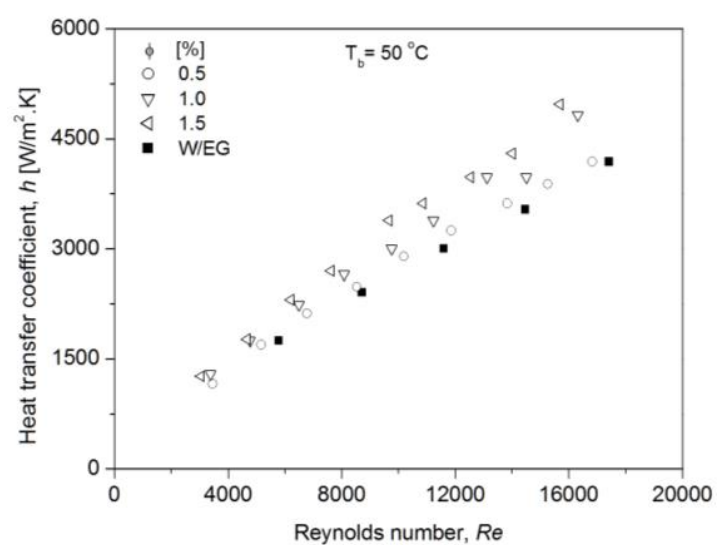

(b) $50^{\circ} \mathrm{C}$

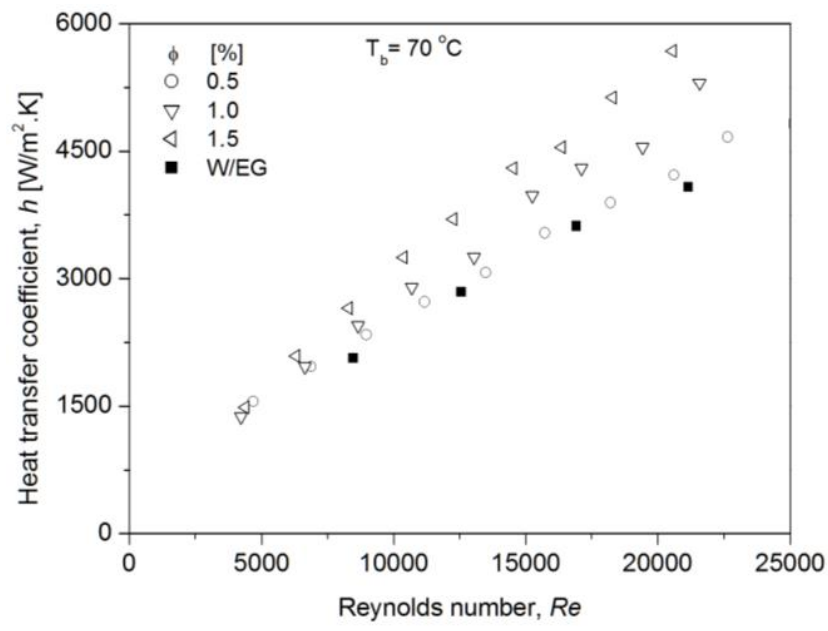

(c) $70^{\circ} \mathrm{C}$

Figure 3. Relationship between heat transfer coefficient and Reynolds number for different volume concentration.

Table 2. Heat transfer coefficient enhancement variation with temperature.

\begin{tabular}{ccccc}
\hline & \multicolumn{4}{c}{ Enhancement $(\%)$} \\
\hline & $\phi(\%)$ & 0.5 & 1 & 1.5 \\
\hline Temperature, & 30 & -15.36 & -2.84 & 9.72 \\
T $\left({ }^{\circ} \mathrm{C}\right)$ & 50 & 3.26 & 12.45 & 22.75 \\
& 70 & 5.68 & 14.85 & 28.92 \\
\hline
\end{tabular}




\section{CONCLUSIONS}

The heat transfer coefficient increases with working temperature and volume concentration. The heat transfer performance of $\mathrm{TiO}_{2}$ nanofluid shows enhancement compared with the base fluid. In the light of the results obtained, maximum enhancement is $28.5 \%$ compared with base fluid at $1.5 \%$ volume concentration and working temperature of $70^{\circ} \mathrm{C}$. The effect of temperature is significant in relation to heat transfer performance at high volume concentrations and high temperature in the range studied. For a mixed base fluid, nanofluid at $30^{\circ} \mathrm{C}$ experiences lower heat transfer because of the particle migration mechanism.

\section{ACKNOWLEDGEMENTS}

The financial support by Universiti Malaysia Pahang (UMP) under RDU1403110 and GRS140354; also Automotive Excellence Center (AEC) under RDU1403153 are gratefully acknowledged.

\section{REFERENCES}

[1] Godson L, Raja B, Lal DM, Wongwises S. Enhancement of heat transfer using nanofluids - an overview. Renewable and Sustainable Energy Reviews. 2010;14:629-41.

[2] Syam Sundar L, Sharma KV. An experimental study on heat transfer and friction factor of Al2O3 nanofluid. Journal of Mechanical Engineering and Sciences. 2011;1:99-112.

[3] Azmi WH, Sharma KV, Mamat R, Anuar S. Nanofluid properties for forced convection heat transfer: An overview. Journal of Mechanical Engineering and Sciences. 2013;4:397-408.

[4] Hussein AM, Sharma KV, Bakar RA, Kadirgama K. Heat transfer enhancement with nanofluids - A review. Journal of Mechanical Engineering and Sciences. 2013;4:452-61.

[5] Choi US. Enhancing Thermal Conductivity of Fluids With Nanoparticles. In: Siginer DA, Wang HP, editors. Developments and Applications of NonNewtonian Flows. New York: American Society of Mechanical Engineers. 1995: 99-105.

[6] Eastman JA, Choi SUS, Li S, Thompson LJ, Lee S. Enhanced Thermal Conductivity Through The Development of Nanofluids. Proc Symposium Nanophase and Nanocomposite Materials II. Boston, MA: Materials Research Society. 1997: 3-11.

[7] Fadhillahanafi NM, Leong KY, Risby MS. Stability and thermal conductivity characteristics of carbon nanotube based nanofluids. International Journal of Automotive and Mechanical Engineering. 2013;8:1376-84.

[8] Hussein AM, Bakar RA, Kadirgama K, Sharma KV. Experimental measurements of nanofluids thermal properties. International Journal of Automotive and Mechanical Engineering. 2013;7:850-63.

[9] Ravisankar B, Tara Chand V. Influence of nanoparticle volume fraction, particle size and temperature on thermal conductivity and viscosity of nanofluids- A 
review. International Journal of Automotive and Mechanical Engineering. 2013;8:1316-38.

[10] Said Z, Sajid MH, Alim MA, Saidur R, Rahim NA. Experimental investigation of the thermophysical properties of $\mathrm{AL}_{2} \mathrm{O}_{3}$-nanofluid and its effect on a flat plate solar collector. International Communications in Heat and Mass Transfer. 2013;48:99-107.

[11] Sundar LS, Singh MK, Sousa ACM. Thermal conductivity of ethylene glycol and water mixture based $\mathrm{Fe} 3 \mathrm{O} 4$ nanofluid. International Communications in Heat and Mass Transfer. 2013;49:17-24.

[12] Javadi FS, Sadeghipour S, Saidur R, BoroumandJazi G, Rahmati B, Elias MM, et al. The effects of nanofluid on thermophysical properties and heat transfer characteristics of a plate heat exchanger. International Communications in Heat and Mass Transfer. 2013;44:58-63.

[13] Paul G, Philip J, Raj B, Das PK, Manna I. Synthesis, characterization, and thermal property measurement of nano- $\mathrm{Al}_{95} \mathrm{ZnO}_{5}$ dispersed nanofluid prepared by a two-step process. International Journal of Heat and Mass Transfer. 2011;54:3783-8.

[14] Mahendran M, Lee GC, Sharma KV, Shahrani A. Performance of evacuated tube solar collector using water-based titanium oxide nanofluid. Journal of Mechanical Engineering and Sciences. 2012;3:301-10.

[15] Rao GS, Sharma KV, Chary SP, Bakar RA, Rahman MM, Kadirgama K, et al. Experimental study on heat transfer coefficient and friction factor of $\mathrm{Al} 2 \mathrm{O} 3$ nanofluid in a packed bed column. Journal of Mechanical Engineering and Sciences. 2011;1:1-15.

[16] Rahman MM, Kadirgama K, Ab Aziz AS. Artificial neural network modeling of grinding of ductile cast iron using water based $\mathrm{SiO} 2$ nanocoolant. International Journal of Automotive and Mechanical Engineering. 2014;9:1649-61.

[17] Sharma KV, Sundar LS. Laminar convective heat transfer and friction factor of $\mathrm{Al}_{2} \mathrm{O}_{3}$ nanofluid in circular tube fitted with twisted tape inserts. International Journal of Automotive and Mechanical Engineering. 2011;3:265-78.

[18] Hojjat M, Etemad SG, Bagheri R, Thibault J. Turbulent forced convection heat transfer of non-Newtonian nanofluids. Experimental Thermal and Fluid Science. 2011;35:1351-6.

[19] Ding Y, Chen H, He Y, Lapkin A, Yeganeh M, Šiller L, et al. Forced convective heat transfer of nanofluids. Advanced Powder Technology. 2007;18:813-24.

[20] Azmi WH, Sharma KV, Sarma PK, Mamat R, Anuar S. Comparison of convective heat transfer coefficient and friction factor of $\mathrm{TiO}_{2}$ nanofluid flow in a tube with twisted tape inserts. International Journal of Thermal Sciences. 2014;81:84-93.

[21] Duangthongsuk W, Wongwises S. Heat transfer enhancement and pressure drop characteristics of $\mathrm{TiO} 2-$ water nanofluid in a double-tube counter flow heat exchanger. International Journal of Heat and Mass Transfer. 2009;52:2059-67.

[22] Azmi WH, Sharma KV, Sarma PK, Mamat R, Najafi G. Heat transfer and friction factor of water based $\mathrm{TiO}_{2}$ and $\mathrm{SiO}_{2}$ nanofluids under turbulent flow in a tube. International Communications in Heat and Mass Transfer. 2014;59:30-8.

[23] ASHRAE Handbook - Fundamentals (SI Edition). Atlanta: American Society of Heating, Refrigerating and Air-Conditioning Engineers, Inc.; 2009. 
[24] Abdul Hamid K, Azmi WH, Mamat R, Usri NA. Thermal conductivity enhancement of aluminium oxide nanofluid in ethylene glycol. Applied Mechanics and Materials. 2014; 660:730-4.

[25] Anoop KB, Kabelac S, Sundararajan T, Das SK. Rheological and flow characteristics of nanofluids: Influence of electroviscous effects and particle agglomeration. Journal of Applied Physics. 2009;106: 034909.

[26] Usri NA, Azmi WH, Mamat R, Abdul Hamid K. Viscosity of aluminium oxide $\left(\mathrm{Al}_{2} \mathrm{O}_{3}\right)$ nanoparticle dispersed in ethylene glycol. Applied Mechanics and Materials. 2014;. 660:735-9.

[27] Abdul Hamid K, Azmi WH, Mamat R, Usri NA. Heat transfer performance of titanium oxide in ethylene glycol based nanofluids under transition flow. Applied Mechanics and Materials. 2014; 660:684-8.

[28] Chen H, Yang W, He Y, Ding Y, Zhang L, Tan C, et al. Heat transfer and flow behaviour of aqueous suspensions of titanate nanotubes (nanofluids). Powder Technology. 2008;183:63-72.

[29] Ho CJ, Lin YJ. Turbulent forced convection effectiveness of alumina-water nanofluid in a circular tube with elevated inlet fluid temperatures: An experimental study. International Communications in Heat and Mass Transfer. 2014;57:247-53. 